\title{
Oxidative stress and enzymatic scavenging of superoxide radicals induced by solar UV-B radiation in Ulva canopies from southern Spain*
}

\author{
KAI BISCHOF ${ }^{1,4}$, PAUL J. JANKNEGT ${ }^{1}$, ANITA G.J. BUMA ${ }^{1}$, JAN W. RIJSTENBIL ${ }^{2}$, \\ GLORIA PERALTA ${ }^{2,3}$ and ANNEKE M. BREEMAN ${ }^{1}$
}

${ }^{1}$ University of Groningen, Department of Marine Biology, Kerklaan 30, 9750 AA Haren, The Netherlands. ${ }^{2}$ Netherlands Institute of Ecology, Centre for Estuarine and Coastal Research, 4400 AC Yerseke, The Netherlands. ${ }^{3}$ Universidad de Cádiz, Facultad de Ciencias del Mar y Ambientales, 11510 Puerto Real, Spain. ${ }^{4}$ Alfred Wegener Institute for Polar and Marine Research, 27515 Bremerhaven, Germany. E-mail: kbischof@awi-bremerhaven.de

\begin{abstract}
SUMMARY: The generation of reactive oxygen species (ROS) and scavenging of the superoxide radical by superoxide dismutase (SOD) was studied in mat-like canopies of the green macroalga Ulva rotundata Bliding in a tidal brine pond system in southern Spain. Artificial canopies were covered with different cut-off filters, generating different radiation conditions. ROS and SOD were assessed after three days of exposure. ROS induced lipid peroxidation depended on the position of individual thalli within the canopy and on radiation conditions. Samples exposed to the full solar spectrum were most affected, whereas samples either exposed to photosynthetically active radiation (PAR) alone or UV radiation without PAR exhibited fewer peroxidation products. The activity of SOD appeared to be controlled by the impinging UV-A and UV-B radiation and also increased in response to oxidative stress. The results provide evidence for additive effects of high PAR and UV-B under field conditions and support the previously proposed hypothesis that UV-B effects are mediated by an inhibition of the xanthophyll cycle, which increases ROS production and, consequently, causes oxidative damage to components of the photosynthetic machinery, such as proteins and pigments.
\end{abstract}

Key words: macroalgae, photosynthesis, reactive oxygen species, superoxide dismutase, Ulva, UV radiation.

RESUMEN: ESTRÉS OXIDATIVO Y ELIMINACIÓN ENZIMÁTICA DE RADICALES SUPERÓXIDOS INDUCIDOS POR RADIACIÓN UV-B EN DOSELES DE ULVA DEL SUR DE ESPAÑA. - La generación de especies de oxígeno reactivo (ROS) y la eliminación de radicales superóxido por medio de la enzima superóxido dismutasa (SOD) fueron estudiadas en poblaciones con estructura en dosel de la clorofita Ulva rotundata Bliding en los caños de una antigua salina litoral en el Sur de España. Doseles artificiales de $U$. rotundata se cubrieron con filtros de ventana, generando diferentes radiaciones de cultivo. La presencia de ROS y SOD se evaluó después de tres días de exposición. Los niveles de lípidos peroxidados, producidos por la presencia de ROS, variaron según la posición de los talos individuales dentro de la estructura en dosel, y según la radiación de cultivo. Los talos expuestos al espectro solar completo fueron los más afectados, mientras que aquellos expuestos únicamente a radiación fotosintéticamente activa (PAR), con o sin radiación UV, y radiación UV sin PAR, generaron menos productos de peroxidación. La actividad de la SOD parece estar controlada por la radiación UV-A y UV-B incidente en cada talo, incrementando, en cualquier caso, como respuesta al estrés oxidativo. Estos resultados proporcionan evidencias suficientes para concluir que radiaciones altas de PAR y UV-B, típicas en condiciones naturales, tienen efectos negativos sinérgicos. Así mismo, los resultados aquí presentados soportan la hipótesis de que los efectos de la radiación UV-B están mediados por la inhibición del ciclo de la xantofila, lo cual produce un incremento de la producción de ROS y, consecuentemente, provoca daños oxidativos a componentes de la maquinaria fotosintética, como proteínas y pigmentos.

Palabras clave: macroalgas, fotosíntesis, especies de oxígeno reactivo, superóxido dismutasa, Ulva, radiación UV. 


\section{INTRODUCTION}

In eutrophic shallow coastal zones, Ulva species often cause green tides. Thalli occur in dense, multilayered mats floating on the water surface (Hernández et al., 1997; Vergara et al., 1997, 1998). The top layer is regularly exposed to high solar radiation, whereas the shaded layers receive reduced light intensities (Vergara et al., 1997, 1998). These so called Ulva mats are frequently observed within soft bottom habitats along the shallow coastal zones of southern Spain. Previous studies have shown the importance of canopy arrangement for maintaining high production rates of algal assemblages within these highly eutrophic systems (Pérez-Lloréns et al., 1996; Hernández et al., 1997). A recent study on the effects of solar UV radiation on Ulva canopies proposed canopy formation as an ecological strategy for shielding productive material from harmful UV-B radiation (Bischof et al., 2002b): the bleached top layers of mats, which exhibit marked absorption of solar radiation only in the UV-B range of the spectrum, shield the subcanopy layers. In the same study it was also proposed that under field conditions the combination of high irradiance of photosynthetically active radiation (PAR) and UV-B radiation results in the loss of photosynthetic proteins and pigments, probably due to a high production of reactive oxygen species (ROS) in photosynthesis. This was indicated by an impaired non-photochemical quenching (reflecting heat dissipation) and reduced activity of the xanthophyll cycle. The UV-B induced impairment of violaxanthin de-epoxidation has previously been demonstrated in isolated chloroplasts and intact leaves of higher plants (Pfündel et al., 1992), but also for macroalgae under field conditions (Bischof et al., 2002a, b).

As a consequence of radiative stress, the production of ROS, such as singlet oxygen, superoxide ions and hydrogen peroxide, increases, which may result in oxidative damage to DNA, proteins and lipids (Halliwell and Gutteridge, 1989). For example, the superoxide radical is usually generated via the "Mehler reaction" in photosynthesis. Lack of $\mathrm{NADP}^{+}$may result in electron transfer from reduced ferredoxin to oxygen, thus generating the superoxide radical. As a ROS scavenging mechanism, the enzyme superoxide dismutase (SOD) catalyses the detoxification of superoxide ions yielding $\mathrm{H}_{2} \mathrm{O}_{2}$ and oxygen. The damage induced by ROS can be demonstrated by the measurement of malondialdehyde (MDA) production, representing a product of ROS induced lipid peroxidation (Heath and Packer, 1968).

We hypothesise that UV-B effects on photosynthesis of Ulva canopies observed by Bischof et al. (2002b) were caused by reactive oxygen species. This was further examined in the present paper: measurements of ROS-induced MDA production and enzyme activity of SOD provide evidence for additive and also synergistic effects on macroalgal photosynthesis imposed by different wavelength ranges, resulting in photooxidative stress under field conditions.

\section{MATERIAL AND METHODS}

The experiment was conducted between 25 July and 25 August 2001 in the "Salinas de la Calavera" $\left(36^{\circ} 25^{\prime} \mathrm{N}, 6^{\circ} 13^{\prime} \mathrm{W}\right.$; property of Acuinova, San Fernando, Spain) within the "Parque Natural Bahia de Cádiz", Spain. The site consists of various parallel creeks, which are interconnected by tide influenced channels. Tides are semi diurnal with an average tidal range of $0.8 \mathrm{~m}$. The soil is formed of sedimental stones with an extended soft bottom layer (up to $0.5 \mathrm{~m}$ ). Within the chosen central creek, salinity varied between 34 and $40 \%$ o depending on tidal conditions. Water temperature varied with tidal conditions and solar insulation in the range of $22-27^{\circ} \mathrm{C}$. Vertical attenuation coefficients $\left(\mathrm{K}_{\mathrm{d}}\right)$ of downward PAR varied between 0.6 and $1.0 \mathrm{~m}^{-1}$, as determined by parallel irradiance measurements conducted at different water depths using two cosine-corrected flathead under-water sensors ( $\mathrm{Li}$ 192 SA, Licor Quantum, Lincoln, USA) connected to a Licor Li-1000 data logger. During the experimental period, sunny conditions prevailed, under which maximal solar irradiance of up to $500 \mathrm{~W} \mathrm{~m}$ 2 PAR (400-700 nm), $80 \mathrm{~W} \mathrm{~m}^{-2}$ UV-A (315-400 $\mathrm{nm})$ and $1,8 \mathrm{~W} \mathrm{~m}^{-2} \mathrm{UV}-\mathrm{B}(280-315 \mathrm{~nm})$ were measured (data from continuous UV-measurements from Southern Spain were downloaded from www.eldonet.org). Further details on the physicochemical conditions during the experimental period are given by Bischof et al. (2002b).

The study site was densely populated by Ulva rotundata Bliding, which usually forms extended floating mats. Individual thalli can grow up to a size of $1.5 \times 0.6 \mathrm{~m}$. Artificial Ulva canopies were designed by arranging four well-pigmented subcanopy Ulva layers between two layers of nylon mesh (approx. 22 x $22 \mathrm{~cm}$; see Fig. 1). Five different 


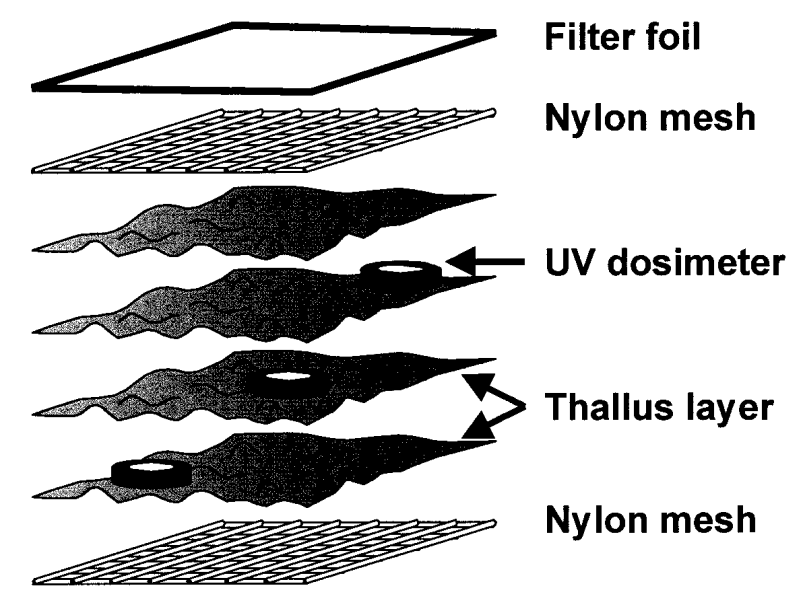

FIG. 1. - Design of artificial canopies, see Material and methods for details.

radiation treatments were generated by using filter foils in the top layer. The filter foils used were: Ultraphan 395 (Digefra, Munich, Germany) to exclude UV-A and UV-B, and Folex 320 (Folex, Dreieich, Germany) to exclude UV-B. Additionally, Ultraphan 295 was used to be able to discriminate the additional effect of the coverage of samples with the plastic filter foils compared to the samples exposed to unfiltered radiation. The optical characteristics of the respective filters were previously published by Pérez-Rodríguez et al. (1998) and Bischof et al. (2002b). Additionally, mats were exposed to unfiltered solar radiation and also placed under UG-5 filters (Schott, Mainz, Germany), which almost completely absorb PAR but exhibit a high transmission below $400 \mathrm{~nm}$, allowing both UV-A and UV-B to pass. Canopies exposed to unfiltered solar radiation were equipped with biological UVdosimeters (Viospor, Biosense, Germany; see Quintern et al. (1992) and Furusawa et al. (1998) for reference) under Ulva layer one, two and three (see Fig. 1). The results of the dosimeters were weighted to the MED (minimal erythemal dose) function and reveal that after three days of exposure only $3.7 \%$ of the atmospheric fluence of this particularly harmful radiation in the UV-B range was transmitted through the first thallus layer.

Six canopies were arranged per treatment and exposed independently. The individual arrangements were attached to a floating system, which guaranteed even exposure of material at the water surface and the proper position of canopies during the time of exposure. After three days of exposure, the respective layers of canopies from the different radiation treatments were separated and samples for physiological analyses were taken randomly. Algal material was collected around noon, immediately frozen in liquid nitrogen and stored at $-80^{\circ} \mathrm{C}$ until analysis.

As an indication of oxidative stress, lipid peroxidation was studied as malondialdehyde (MDA) formation. The procedure described by Heath and Packer (1968) was modified as follows. In a mortar, $200 \mathrm{mg}$ FW of frozen algal samples were ground to a fine powder using liquid nitrogen and seasand. Subsequently, the powder was dissolved in $1 \mathrm{ml} \mathrm{dd}$ $\mathrm{H}_{2} \mathrm{O}$. One $\mathrm{ml}$ of $0.5 \%$ thiobarbituric acid (dissolved in $20 \%$ trichloric acetic acid) was added and samples were incubated at $98^{\circ} \mathrm{C}$ for $30 \mathrm{~min}$ and chilled again on ice. Samples were centrifuged for $10 \mathrm{~min}$ at $20,000 \mathrm{x}$ g. Absorption of the supernatant was measured at $532 \mathrm{~nm}$ with a Cary $3 \mathrm{E}$ spectrophotometer (Varian Inc., Palo Alto, CA, USA). To correct for non-specific turbidity, absorption at $600 \mathrm{~nm}$ was subtracted. For calculation, the extinction coefficient $155 \mathrm{mM}^{-1} \mathrm{~cm}^{-1}$ was used. As in the course of exposure the top layers of the mats were subject to disintegration, a dilution effect (due to leakage from dead cells) on tested parameters had to be taken into account. Therefore, neither weight nor thallus surface were regarded as reliable parameters for MDA normalisation. Since ROS production is strongly dependent on photosynthetic electron transport (Rijstenbil et al., 2000), and thus chlorophyll content, we chose to express results as $\mu$ mole MDA * unit of chlorophyll $a^{-1}$ as follows: dividing MDA per FW by chlorophyll per FW, the weight (and therefore also actual chlorophyll content within the respective thallus layer) becomes irrelevant $[(\mathrm{MDA} / \mathrm{FW}) /(\mathrm{CHL} / \mathrm{FW})=(\mathrm{MDA} / \mathrm{CHL})]$. The resulting relation just represents the MDA formed per unit chlorophyll, so the actual Chl content in the cells is irrelevant in this calculation. Data on chlorophyll concentrations found in the same experiment are given by Bischof et al. (2002b).

The activity of SOD was measured by applying a photometric enzyme assay, generally following the xanthine-oxidase-cytochrome $c$ reduction method (McCord and Fridovich, 1969). In short: frozen samples were ground to a fine powder and extracted in a $50 \mathrm{mM}$ Kpi buffer containing $50 \mathrm{mM} \mathrm{KH_{2 }} \mathrm{PO}_{4}$ with $0.1 \mathrm{mM}$ EDTA at $\mathrm{pH} 7$. Activity of SOD was measured at $550 \mathrm{~nm}$ after the addition of $0.6 \mathrm{mM}$ xanthine (Sigma X-0626), 4.5 units xanthine oxidase (Sigma X-4875) per $\mathrm{ml}$, and $60 \mu \mathrm{M}$ cytochrome $c$ (Merck 124804). Enzyme activity was 
expressed as units per mg of total extracted protein. Protein content of extracts was determined using a commercial protein assay (Bio Rad, Hercules, USA), and calculated according to a calibration curve prepared with known concentrations of bovine serum albumine. Expressing SOD activity per extracted protein does not necessarily refer to the actual protein content of samples, thus giving a much clearer picture on the actual activation state of SOD in the respective samples, provided that the relative loss in protein content due to UV induced damage or cellular disintegration affects all proteins to the same extent. Data on protein content within the different thallus layers are given by Bischof et al. (2002b).

All measurements on MDA formation were performed using triplicate samples, whereas SOD activity measurements could be performed in duplicates only. Mean values and standard deviations were calculated, and tests for statistically significant differences were performed by applying ANOVA and Fisher's least significant difference (LSD) procedure at the $95 \%$ confidence level.

\section{RESULTS}

Levels of ROS induced lipid peroxidation varied markedly with respect to radiation conditions and position of thallus layers within the canopy (Fig. 2). Material collected from the subcanopy initially exhibited MDA concentrations of about $127 \mu$ mole MDA * unit chlorophyll $a^{-1}$. Statistically significant increases in MDA concentrations were only found in the first two layers under the full solar spectrum $(\mathrm{PAR}+\mathrm{UV}-\mathrm{A}+\mathrm{UV}-\mathrm{B}=$ unfiltered radiation and 295 filter; $\mathrm{p}<0.05)$ compared to the initial values. The highest MDA concentrations were measured in the top layer of the mats exposed to unfiltered radiation, with maximum values up to $250 \mu$ mole

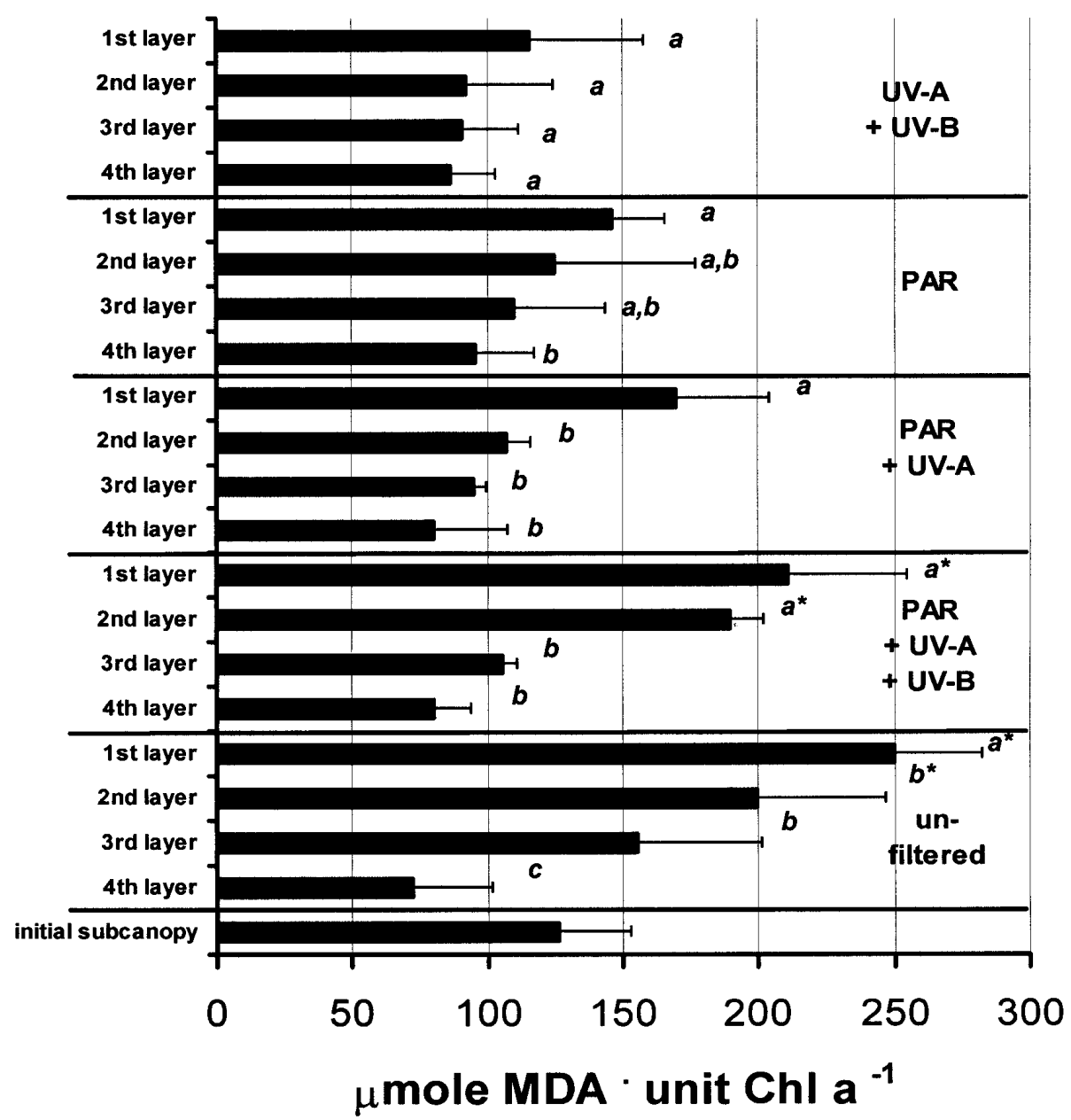

FIG. 2. - Concentration of malondialdehyde (MDA) with respect to the position of thalli within the artificial canopies and radiation conditions. Different letters indicate significant differences between layers within light treatments, asterisks indicate significant differences from initial values $(\mathrm{p}<0.05)$. 


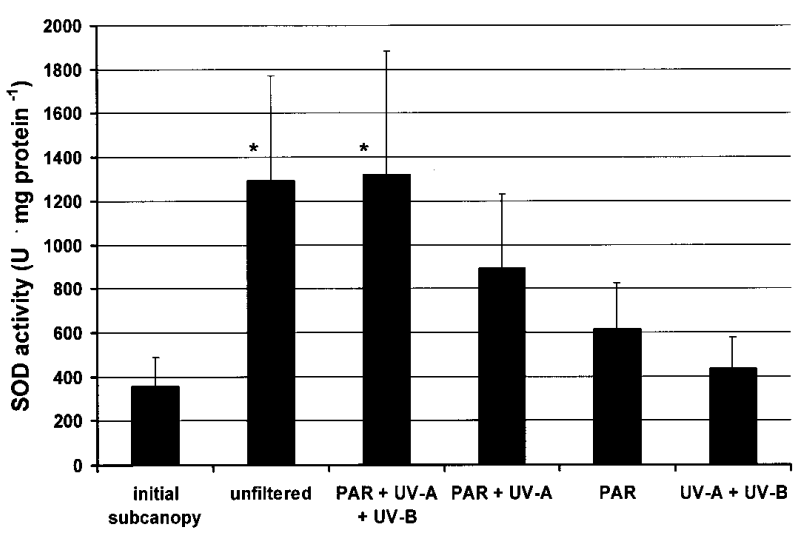

FIG. 3. - Activity of superoxide dismutase (SOD) in top layers of artificial canopies with respect to radiation conditions. Asterisks indicate significant differences from initial values $(\mathrm{p}<0.05)$.

MDA * unit chlorophyll $a^{-1}$. Within the canopies, a significant gradient in MDA concentration was observed among the respective thallus layers in all treatments except under UV-A + UV-B, under the exclusion of PAR. Samples exposed to PAR + UV-A (320 filter) exhibited a tendency to have a lower MDA concentration than those also exposed to UVB. MDA concentrations in samples exposed either to PAR under UV exclusion (395 filter) or to UV-A + UV-B under PAR exclusion (UG-5 filter) did not differ significantly from the initial values measured in the subcanopy specimens.

The SOD activity showed marked variations in top layers of canopies exposed to different radiation conditions (Fig. 3). The lowest SOD activity was measured in the initially sampled material from the subcanopy (364 $\mathrm{U} * \mathrm{mg}$ protein ${ }^{-1}$ ) and was in the same range as in the top layers kept under UV without PAR (UG-5 filter), and under PAR without UV. Under PAR and UV-A, a trend to higher SOD activities was observed, although it was not statistically significant. Significantly higher activities were measured in the top layers of mats exposed to the whole solar range (PAR + UV-A + UV-B and unfiltered; $\mathrm{p}<0.05$ ).

\section{DISCUSSION}

The results demonstrate the interactive effects of the different wavelength ranges involved in the production and scavenging of ROS in Ulva under field conditions. The combination of high PAR and UV-B leading to the destruction of pigments and proteins involved in photosynthesis in the same set of experiments was described by Bischof et al. (2002b): Chl $a, b$ and total protein content, and concentration of RubisCO decreased sharply under exposure to the full solar range, while exposure to solar PAR alone only resulted in minor adverse effects. Exposure to UV under exclusion of PAR did not harm any of the parameters tested. However, as measurements of ROS production were not included in the latter study, evidence for the proposed mechanism of a reduced xanthophyll cycle activity induced by UV-B radiation and the consequent high production of ROS due to high levels of PAR was still lacking. The present results confirm this hypothesis; furthermore, they show how the enzymatic defence systems are triggered by changes in spectral composition.

All parameters tested in the present study and in the studies by Bischof et al. (2002b) and Vergara et al. $(1997,1998)$ depend on the respective position of thallus layers within the canopy arrangements. This is due to the steep gradient in visible (especially blue and red light; Vergara et al. 1997) and, even more, ultraviolet radiation (Bischof et al., 2002b) due to self shading effects. Vergara et al. (1997) estimated vertical attenuation coefficients for PAR within Ulva canopies $\left(\mathrm{K}_{\mathrm{u}}\right)$ that depended on the sediment load covering the mats. These values ranged from 0.444 per layer (clean tissue) up to four times higher numbers when high sediment loads (about 30\% dry weight) were deposited over algal thalli.

The presence of ROS was indicated by the changes in MDA concentration, which also showed marked differences with respect to the position of thallus layers within the mat. The usefulness of expressing MDA content per unit of chlorophyll is apparent, as one of the major results is that both MDA production and SOD activity are stimulated by PAR (in addition to UV). This shows that PARdriven electron transport plays a key role in the ROS production, resulting in MDA formation. The PARdriven photosynthetic electron transport appeared to be required for the generation of superoxide anions at PSI. When UV is added to PAR, an excess of superoxide appeared that, via the Haber-Weiss reaction, enhanced the formation of hydroxyl radicals causing lipid peroxidation. Since ROS production, and thus MDA levels, are clearly dependent on photosynthetic electron transport (see Rijstenbil et al., 2000), we believe that linking the ROS production (lipid peroxidation) with chlorophyll contents is appropriate. However, the MDA assay used here fails to detect all peroxidation products, therefore it should be regarded as an estimate of ROS induced damage rather than a numeric quantification of 
oxidative stress. Information on MDA levels in macroalgae is very scarce. The measured values of the present study are in the same range as MDA concentrations measured in a study on lipid peroxidation of thylakoid membranes of wheat (Dawar et al., 1998). The production of ROS was clearly dependent on radiation conditions and exhibited marked additive effects of the PAR and the UV range. Measured MDA levels in either the PAR (without UV) or the UV (without PAR) exposed material were in the same range as in the initially sampled material from the subcanopy, whereas the combination of UV and PAR led to a substantial increase in ROS production. This strongly supports the hypothesis that under field conditions harmful effects on photosynthesis are generated by additive effects of the different wavelength ranges.

Studies on isolated thylakoids and intact leaves of higher plants as well as on green intertidal macroalgae under field conditions have shown UVB induced inhibition of the xanthophyll cycle (Pfündel et al., 1992; Bischof et al., 2002a, b). The impaired ability for non-photochemical quenching may result in an increased production of ROS under high irradiances of PAR (Asada and Takahashi, 1987). This will result in photooxidation of components of the photosynthetic apparatus (pigments, proteins). The ability of macroalgae to scavenge ROS was previously demonstrated by Collen and Davison (1999a, b) and Aguilera et al. (2002a, b). It was shown that the species specific efficiency of ROS scavenging is partly related to zonation patterns of species on the shore (Collen and Davison, 1999a, b). Thus, a marked ability of the intertidally occurring Ulva to remove ROS can be assumed. The measured activities of SOD were in the same range as previously reported for the green macroalga Monostroma arcticum collected from the Arctic Kongsfjord (Aguilera et al., 2002b). This species is also able to increase SOD activity in response to seasonally increasing irradiances (e.g. in response to sea ice break-up, changes in water turbidity etc.; Aguilera et al., 2002a). Field experiments on the green alga Acrosiphonia penicilliformis also showed an increase in SOD activity (Aguilera et al., 2002b) in response to UV exposure.

At first glance our results seem to suggest an increase in SOD activity triggered by the UV range of the solar spectrum, as activities are elevated under the full solar range. However, the observed pattern in MDA formation indicates that SOD may be directly activated by the presence of ROS rather than by differences in light quality. The samples exposed to UV-A + UV-B under exclusion of PAR did not exhibit a high ROS production and SOD activity was also low in these specimens. As under this filter type (UG-5) photosynthesis is only driven by the low irradiance of incoming red light transmitted by the filter, hardly any ROS are produced in photosynthesis. In contrast, samples exposed to solar PAR, but shielded from UV, do photosynthesise at high rates, but are capable of responding to the impinging high irradiance of PAR through an increase in nonphotochemical quenching due to an activated xanthophyll cycle (Bischof et al., 2002b). Consequently, ROS generation in photosynthesis is low and so is SOD activity (this study). The previously described impairment of the xanthophyll cycle, and consequently non-photochemical quenching in samples exposed to the full solar range (Bischof et al., 2002b), is now shown to be linked to a high ROS production. Previously, Rijstenbil et al. (2000) have shown an increase in active oxygen production at increasing photosynthetic rates and a further rise in ROS production in the brown alga Fucus spiralis after PAR is supplemented with UV-B. Recent studies on pea plants have proposed ROS to be directly involved in the signal transduction pathway to adjust gene expression in response to UV exposure (Mackerness et al., 1999). Changes in expression of SOD encoding genes under UV exposure have not yet been studied, but it was shown in the latter study that the expression of genes which are generally related to protective mechanisms against UV-B exposure is up-regulated in response to a UV induced increase in ROS production. Furthermore, the persistent high activity of SOD even in the top layers under unfiltered solar radiation suggests a very high resistance of this enzyme to abiotic stress. Under these conditions other critical components such as RubisCO and photosynthetic pigments were seriously damaged (Bischof et al., 2002b). However, the induced rise in activity of ROS scavenging enzymes like SOD does not seem to provide sufficient protection to avoid loss of photosynthetic proteins and photobleaching of pigments as a result of photooxidation in top layers of the canopy. The results presented here strongly support the proposed pathway of UV$B$ induced inhibition of photosynthesis under field conditions. Namely, a UV-B induced impairment of the xanthophyll cycle (Bischof et al., 2002b) will result in an increase in oxidative stress (this study) and photooxidation under high irradiances of PAR (Bischof et al., 2002b). These results contribute to 
the understanding of the ecophysiology of Ulva canopies in areas with high solar irradiance, such as the southern coastal areas of Spain. Further studies should now focus on the molecular mechanisms behind the regulation of ROS scavenging enzyme activities.

\section{ACKNOWLEDGEMENTS}

Authors are grateful to Acuinova for granting access to the saltmarsh system, to J.L. Pérez-Lloréns (University of Cádiz) for his support in conducting the experiment, to T. Moerdijk (NIOO-CEMO Yerseke) for technical support, and to W.H. van de Poll (University of Groningen) for helpful remarks on the manuscript. Funding of K.B. by an Emmy Noether grant obtained from the Deutsche Forschungsgemeinschaft (DFG BI 772 1/1) is gratefully acknowledged. Publication 3142N100-KNAW, Netherlands Institute of Ecology, Centre for Estuarine and Marine Ecology, Yerseke, The Netherlands.

\section{REFERENCES}

Aguilera, J., K. Bischof, U. Karsten, D. Hanelt and C. Wiencke. 2002a. Seasonal variation in ecophysiological patterns in macroalgae from an Arctic fjord. II. Pigment accumulation and biochemical defence systems against high light stress. Mar. Biol., 140: 1087-1095.

Aguilera, J., A. Dummermuth, U. Karsten, R. Schriek and C. Wiencke. - 2002b. Enzymatic defences against photooxidative stress induced by ultraviolet radiation in Arctic marine macroalgae. Polar Biol., 25: 432-441.

Asada, K. and M. Takahashi. - 1987. Production and scavenging of active oxygen in photosynthesis. In: D.J. Kyle, C.B. Osmond and C.J. Arntzen (eds.), Photoinhibition, Topics in photosynthesis Vol. 9, pp. 89-109. Elsevier Science Publishers, Amsterdam.

Bischof, K., G. Kräbs, C. Wiencke and D. Hanelt. - 2002a. Solar ultraviolet radiation affects the activity of ribulose-1,5-bisphosphate carboxylase-oxygenase and the composition of photosynthetic and xanthophyll cycle pigments in the intertidal green alga Ulva lactuca L. Planta, 215: 502-509.

Bischof, K., G. Peralta, G. Kräbs, W.H. van de Poll, J.L. PérezLloréns and A.M. Breeman. - 2002b. Effects of solar UV-B radiation on canopy structure of Ulva communities from south- ern Spain. J. Exp. Bot., 53: 2411-2421.

Collen, J. and I.R. Davison. - 1999a. Stress tolerance and reactive oxygen metabolism in the intertidal seaweeds Mastocarpus stellatus and Chondrus crispus. Plant Cell Environ., 22: 1143-1151.

Collen, J. and I.R. Davison. - 1999b. Reactive oxygen production and damage in intertidal Fucus spp. (Phaeophyceae). J. Phycol., 35: 54-61.

Dawar, S., T. Vani and G.S. Singhal. - 1998. Stimulation of antioxidant enzymes and lipid peroxidation in thylakoid membranes of wheat. Biol. Plantarum, 41: 65-73.

Furusawa Y., L.E. Quintern, H. Holtschmidt, P. Koepke and M. Saito. - 1998. Determination of the erythema-effective solar radiation in Japan and Germany with a spore monolayer film optimised for the detection of UVB and UVA-results of a field campaign. Appl. Microbiol. Biotechnol., 50: 597-603.

Halliwell, B. and J.M.C. Gutteridge - 1989. Free radicals in biology and Medicine, $2^{\text {nd }}$ edn. Clarendon Press, Oxford.

Heath, R.L. and L. Packer. - 1968. Photoperoxidation in isolated chloroplasts: I. Kinetics and stochiometry of fatty acid peroxidation. Arch. Biochem. Biophys., 125: 189-198.

Hernández, I., G. Peralta, J.L. Pérez-Lloréns, J.J. Vergara and F.X. Niell. - 1997. Biomass and dynamics of growth of Ulva species in Palmones river estuary. J. Phycol., 33: 764-772.

Mackerness, S.A.H., B.R. Jordan and B. Thomas. - 1999. Reactive oxygen species in the regulation of photosynthetic genes by ultraviolet-B radiation (UV-B: $280-320 \mathrm{~nm}$ ) in green and etiolated buds of pea (Pisum sativum L.). J. Photochem. Photobiol. B: Biol., 48: 180-188.

McCord, J.M. and I. Fridovich. -1969. Superoxide dismutase: an enzymatic function for erythrocuprein (hemocuprein). J. Biol. Chem., 244: 6049-6055.

Pérez-Lloréns, J.L., J.J. Vergara, R.R. Pino, I. Hernández, G. Peralta and F.X. Niell. - 1996. The effect of photoacclimation on the photosynthetic physiology of Ulva curvata and Ulva rotundata (Ulvales, Chlorophyta). Eur. J. Phycol., 31: 349-359.

Pérez-Rodríguez, E., I. Gómez, U. Karsten and F.L. Figueroa. 1998. Effects of UV-radiation on photosynthesis and excretion of UV-absorbing compounds of Dasycladus vermicularis (Dasycladales, Chlorophyta) from southern Spain. Phycologia, 37: 379-387.

Pfündel, E., R.S. Pan and R.A. Dilley. - 1992. Inhibition of violaxanthin de-epoxidation by ultraviolet-B radiation in isolated chloroplasts and intact leaves. Plant Physiol., 98: 1372-1380.

Quintern, L.E., G. Horneck, U. Eschweiler and H. Bücker. - 1992. A biofilm used as ultraviolet-dosimeter. Photochem. Photobiol., 63: 74-78.

Rijstenbil, J.W., S.M. Coelho, M. Eijsackers. - 2000. A method for the assessment of light-induced oxidative stress in embryos of fucoid algae via confocal laserscan microscopy. Mar. Biol., 137: 763-774

Vergara, J.J., J.L. Pérez-Lloréns, G. Peralta and I. Hernández. 1997. Seasonal variation of photosynthetic performance and light attenuation in Ulva canopies from Palmones river estuary. J. Phycol., 33: 773-779.

Vergara, J.J., M. Sebastian, J.L. Pérez-Lloréns and I. Hernández. 1998. Photoacclimation of Ulva rigida and $U$. rotundata (Chlorophyta) arranged in canopies. Mar. Ecol. Prog. Ser., 165: 283-292.

Scient. ed.: T.T. Packard 
